the third orientation is more prevalent than these photographs gave reason to suspect.

It is clearly too early to speculate upon the precise nature of these fibres or to express any opinion as to the way in which they are produced by the plant. So far as the photographs go, however, they certainly give the impression that the fibres might be regarded as 'crystallites' of cellulose, and this would be in harmony with those properties of this particular wall which suggest a high degree of erystallinity. The density, for example, is the highest yet recorded ${ }^{8}$ for cellulose $(1.562)$ and suggests a crystalline/nonerystalline ratio of about 71 per cent. A determination of this ratio made for the senior author by P. H. Hermans of Utrecht (using his X-ray method), to whom our thanks are due, is on the other hand disappointingly low-lying between the values for native fibres and for wood pulp. This may, however, be due to impurities in the specimen sent to him. (A more recent determination on a purified sample is reported by Dr. Hermans to indicate a crystalline/non-crystalline ratio of 67-68 per cent.) The orientation of the fibres must be remarkably perfect, for it must be recalled that in this wall the molecular planes of $6 \cdot 1 \mathrm{~A}$. spacing tend to lie parallel to the wall surface. If the fibres are isodiametric in cross-section, such orientation could arise only through the prevalence of - $\mathrm{OH}$ groups in this plane, and would therefore presumably be initiated at the moment of deposition at the cytoplasm-wall interface, and not secondarily by changes within the mature wall. If, on the other hand, the fibres are flat ribbons (and the photographs as yet offer no evidence on this point), then the orientation could arise mechanically; though even then the orientation is not induced merely by drying, as it is in bacterial cellulose, for precisely the same condition has been demonstrated in undried algæ ${ }^{\circ}$. Finally, it should be noted that since the fibres run uninterruptedly with apparently smooth sides over distances much greater than $10 \mu$ (width of the photographs taken), their appearance lends no support to the 'fringed micelle' hypothesis but tends rather to suggest the continuous, periodically distorted structure suggested by Meyer ${ }^{10}$.

The senior author is indebted to Prof. W. T. Astbury, of the Department of Biomolecular Struc. ture, for valued advice and for placing the facilities of the electron microscope at his disposal, and to the Department of Scientific and Industrial Research for a grant defraying in part the expenses of the algal research.

${ }^{1}$ Reimers, Mitt. Forsch. Inst. Textilstoffe Karlsruhe, 109 (1922). Balls, Proc. Roy. Soc., B, 93, 426 (1922). Dischendorfer, Angewo. Bot., 7, 57 (1925). Steinbrinck, Naturwiss., 15, 978 (1927). Tterson, Chem. Weekbl., 30,6 (1933). 'Preston and Astbury, Proc. Roy. Soc., B, 192 76 (1937) Frey-Wyssling, "Submicroscopic Roy. Soc., B, 122, 76 (1937). Frey-Wyssling, "Submicroscopic Amsterdam, 1948).

2 See, for example, Farr and Eckerson, Contrib. Boyce Thompson Inst., 6, 189 (1934). Farr and Sisson, ibid., 6, 309 (1934).

Dippel, Abh. Senckenb. naturf. Ges., 2, 154 (1879). Schmitz, S. B. niederrhein Ges. Nat.-u. Heilk., 37, 200 (1880). Krabbe, J. wiss. Bot., 18, 346 (1887). Wiesner, "Die Elementarstr. usw." (Wien, 1892). Herzog, "Untersuch. der naturaliche u. Künstliche Seiden" (Dresden, 1910).

- Ruska and Kretscher, Koll. Z., 93, 163 (1940). Marton and McBain, Chem. Products, 1, 16 (1942). Barnes and Burton. Ind. Eng. Chem. (I.E.), 35, 120 (1943). Frey-Wysling and Muhlethaler, $J$. Polymer Sci. (1946).

- Preston, Proc. Leeds Phil. Soc., 2, 185 (1931). Sponsler, Protoplasma, 12, 241 (1931).

- Preston and Astbury, Proc. Roy. Soc., B, 122, 76 (1937).

See, for example, Anderson and Kerr, Ind. Eng. Chem., 80, 48 (1938). Preston, Biol. Rev., 14, 281 (1939).

s Singh and Preston (unpublished).

- Preston and Nicolai (unpublished).

${ }^{10}$ Meyer, "High Polymers", vol. 4 (New York).

\section{THE YOUNG WORKER IN INDUSTRY}

$A \mathrm{~T}$ the discussion on "The Young Worker in A Industry" arranged by Section L (Education) of the British Association on September 13, the two main contributions were from representatives of industry and of the Ministry of Education. In the first paper, which dealt with recent progress in industrial education and training, the authors pointed out that the increasing seale and complexity of British industry since the industrial revolution has been paralleled by a widening appreciation of the need for industrial workers to know something of the principles underlying the industrial arts. The establishment of the mechanics institutes and, later, technical colleges, works' schools and junior technica] schools was part of the practical response to this need, as was, more recently, the setting up of the system of national certificates and the part-time day release by industry of young personnel for technical study.

War-time demands for skilled personnel stimulated realistic thinking and practical developments in the fields of selection and training. War and the post-war economic difficulties have also thrown into relief the social need for maximum economy in the use of man-power. To secure this, it is essential that all young people receive the type of education and training best suited to their interests and natural aptitudes. In this, industry has an important part to play, not only in providing information regarding the types of careers available, but also in establishing training schemes, a function of which should be the assessment under practical conditions of the trainees' suitability, not with the view of 'weeding out' failures so much as of providing training for a suit. able alternative occupation where one course of training proves inappropriate.

The story of national education in Britain between the two World Wars is one of the failure in the practical application of the ideals of the Fisher Act, followed by renewed planning represented by the reports of the Consultative Committee between 1925 and 1938. The trade recessions of this period also checked progress in industrial and commercial training, which was largely in the hands of private enterprise. Some enlightened firms, however, endeavoured to repair the gaps with their works' schools, some of which have a long history. The experience gained in these schools should be of value in connexion with the proposed county colleges. The interest which young workers have in further education is, in most cases, best stimulated by basing it on their work and environment. It is suggested that the initiation courses run by many firms to help young people to bridge the gap between full-time schooling and wage earning could be paralleled by wider courses, designed with the same intent, in the county colleges to be established.

Apprenticeship is an aspect of training in which appreciable progress has been made in industry since the end of the First World War, particularly in the more technical industries such as engineering. Some of the largest concerns have comprehensive appren. ticeship schemes with grades according to the educational levels of entrants-craft apprenticeship for boys from secondary modern and secondary technical schools, student apprenticeship for boys from secondary grammar and from public schools, 
and graduate apprenticeship for young men and women graduates. The difficulty of smaller firms in supporting schemes on such an ambitious scale is one reason for the modern tendericy to discuss and plan apprenticeship schemes at a regional and national level.

Attention has also been given to practical training at the professional level, particularly in the engineering industry. For example, the Institution of Electrical Engineers has published no less than three booklets on training for the electrical industry between 1942 and 1947. The report published in 1947 makes recommendations based on the best in modern training practice in this field, and lays down practical training standards designed to secure for the young professional engineer the width of experience and consequent flexibility necessary for the continued progress of the industry. One specific recommendation is that graduate apprentices should be given leave of absence by their firms to widen their experience not only in Great Britain but also overseas. This recommendation is already being carried out by some firms, and an increasing number of overseas contacts is being made. Many foreign students are coming to Great Britain for engineering training both theoretical and practical. There is no reason why an interchange of craftsmen and technicians, as well as young professional engineers, could not be arranged to give human reality to political and economic union between countries. Already the merits of British methods of training professional engineers are widely recognized. If this reputation can be extended to other industries and vocations, Britain will have made a contribution to world prosperity equal to that made by its scientific men in the field of knowledge.

The second paper, by a representative of the Ministry of Education, indicated that it has always been traditional in Great Britain for our educational institutions to provide for the educational needs and interests of the young worker rather than for the needs of industry as such, and that likewise it is traditional for industry to take responsibility for the practical training of its young workers and to look to our educational institutions for the provision of technology and general education. The needs of industry and the interests of young people are not always identical, and it was to avoid indiscriminate recruitment regardless of aptitudes that the Juvenile Employment Service-now called the Youth Employment Service- was set up. To be fully effective, this Service must have the support of parents, teachers and employers, and be staffed with officers expertly trained in vocational guidance and having a wide knowledge of industrial conditions, so as to effect good 'placing' and to 'follow' up' such placing. Much research is called for in this field.

The educational needs of young workers once they are in industry are very varied, depending on their educational level at entry and on their aspirations; but that further education must be available is now an accepted need for all. Only 30-40 per cent of 'school-leavers' at present receive any further formal education.

Of these, too high a proportion can only acquire their technology at night at the expense of their leisure, and a 40-hour week for the adult should not make us indifferent to the 60-hour week of many apprentices. The larger firms which provide systematic industrial training in works' schools usually have a close link with the technical colleges and appreciate the need for day-time release-200,000 young workers are now released for such training as compared with 40,000 in 1938 . In the smaller works, many are too small to provide even good practical training facilities.

The provision of the 1944 Education Act for compulsory day-time release for young people up to the age of eighteen years tries to provide a partial answer to the problem of the youth who ends his formal education at the school-leaving age of fifteen'partial' because industry must attempt to do its share and the work in the county colleges to be set up under the Act should be complementary to industrial training. Within the past few years, some hundreds of education officers and personnel managers have been appointed by industrial employers for the specific purpose of furthering educational activities, and their influence is already having a marked effect. But such developments are limited in general to the larger industrial firms, and the problem of the smaller firms still remains. There are a number of ways in which the educational system can help to make up for the deficiencies of education and training within industry. One is to send young apprentices to the local technical college for full-time training for one or more years, and another is to release apprentices for 'sandwich' courses in colleges for full-time periods of varying length followed by part-time day release.

Pressure from industry to augment facilities for further education of the young worker is causing the Ministry of Education some embarrassment. The county colleges cannot at present be introduced. The difficulties of interesting the bulk of adolescents, who by the very nature of the industrial structure of Britain must become unskilled workers, in further education are well recognized; but if successful, the education provided by the county college will solve many problems. It will lay a foundation for adult life; develop regular habits of study and work; a pride in a job well done; a healthy interest in recreational pursuits, and fit the young people to play their part in the struggle for industrial survival.

Although not yet ready to introduce the county colleges, the local education authorities in Britain have been asked to plan their provision as an integral part of the whole field of further education. In the large cities there will be one or more central colleges for advanced studies for those over eighteen, and satellite branch colleges to meet the varied needs of those under eighteen. Vocational training and general education will not be separated. In smaller cities and towns there will be small colleges to meet the needs of day and evening courses for youths and adults.

A vital problem in educating youth in industry is to secure permanent liaison between the colleges and industry, and it is hoped that this has been effected by the nation-wide system of Regional Advisory Councils, consisting of representatives of industry and the colleges, the local education authorities and the universities.

The system of further education and training in Britain is complex and untidy; but it has achieved success largely by its voluntary nature, for it is democratic and flexible and comparatively easy to develop in the ways best suited to our people. The technical colleges employ large numbers of expert technologists from industry as teachers, and it is hoped this will continue when the training is carried on in the day-time. The Ministry has been encour- 
aging developments by setting up three training colleges for the training of technical teachers, by facilitating the release of teachers to industry and by encouraging research.

In the discussion which followed the main papers, reference was made to the valuable assistance being given by some industrial concerns to technical education by providing materials and teaching staff. One speaker stressed the need that the selection of vocations should not be made too early; another that small firms had the one great advantage of being able to keep in closer touch with their young workers than can the larger concerns. Listening to all the contributions to the session, one was particularly struck with the obviously growing interest of industry in the education and training of the young worker, and the growing co-operation between employers, organised labour, and the education authorities.

A. P. M. Fleming

\section{SOCIETY FOR APPLIED BACTERIOLOGY}

$\mathrm{T}$ HE annual general meeting and conference of the Society was held during July $27-30$ in the Department of Agriculture, Queen's University, Belfast. Approximately a hundred members and visitors attended the conference.

Agriculture, and particularly dairying, being the principal industry of Ulster, papers on dairy bacteriology predominated among the seventeen contributions submitted to the conference. The first session, on July 27, was devoted to four papers from Northern Ireland workers.

Mr. P. L. Clerkin, of the Bacteriology Division, described the development of the dairy industry in Northern Ireland during the past two decades with particular reference to the methods of bacteriological control. A feature of the Northern Ireland procedure for raw milk is the classification of liquid supplies into three grades designated simply $A, B$ and $C$. Grade $A$ is the produce of tuberculin-tested herds, bottled on the farm and sold raw. It must conform to fairly high bacteriological standards. Grades $B$ and $C$ have lower bacteriological standards and the bulk of such supplies is pasteurized. To assist the ready identification of the milk by the consumer, coloured labels, bottle-caps, etc., were assigned for each grade. This procedure was of interest since the authorities in Great Britain have consistently masked the identity of graded milk supplies under names which convey little or no information to the consumer. Legislation controlling ice-cream quality was introduced in Northern Ireland in 1938 and the Bacteriology Division advised on suitable hygienic standards. In this field, the Ulster authorities have been in advance of England and Wales.

Drs. Lamont and Kerr and Mr. McGirr, of the Northern Ireland Veterinary Division, submitted a paper on the Stormont technique of tuberculin testing. This technique was based on observations indicating that, in the tuberculous bovine, intradermal tuberculin injections exhibited increased sensitivity to a second tuberculin injection given seven days after the primary inoculation. The diagnostic feature is the increase in skin thickness and not the nature of the reaction. Results are now available for 590 animals subjected to the new procedure and afterwards slaughtered for post-mortem examination.
The results showed that the Stormont test had a total error of 3.4 per cent, of which 2 per cent were undetected infected animals.

Lamont and his co-workers have also studied the white blood cell changes in relation to tuberculin testing with particular reference to the new technique. The most striking finding is that the blood reaction with the Stormont technique is very marked, there being a pronounced rise in the polymorph-lymphocyte ratio. The maximum alteration in the ratio appears at varying periods, hence for diagnostic purposes multiple bleeding would be necessary. Using white blood cells, Lamont and his colleagues have succeeded in passively transferring tuberculin sensitivity from the bovine to guinea pigs. These findings offer fairly concrete proof of the presence of the antibody responsible for tuberculin sensitivity. In general, this work supports the thesis recently propounded in a number of American publications that white blood cells and particularly lymphocytes play a very important part in the genesis and manifestations of many immune phenomena.

Dr. Pearson, also of the Veterinary Division of the Ministry, presented a paper on the limitations of penicillin in the treatment and control of bovine mastitis. The North of Ireland experience indicates that clinical mastitis, as encountered by the veterinary surgeon, requires much more individual consideration than is usually given, before penicillin is prescribed. The symptoms of streptococeal and staphylococcal infections are becoming more and more difficult to differentiate, and in Ulster in recent years there has been a definite increase in staphylococcal infections of the udder. In many of these cases little or no response has been shown to penicillin therapy, the organisms being invariably penicillin-resistant. This resistance may possibly have developed during previous penicillin treatment of sporadic mastitis. Strains of resistant streptococci have not become such a problem although such strains undoubtedly exist. Treatment of Corynebacterium pyogenes mastitis with penicillin has been found to be a waste of time and money. During recent years there has been a marked increase in the number of samples from clinically positive cases of mastitis, where it has been impossible to detect any causal organisms either culturally or microscopically.

Mr. J. G. Murray, of the Bacteriology Division, contributed a paper on ropy contamination of pasteurized milk. In a recent outbreak the principal source of such organisms was found to be contaminated milk bottles, Bacterium aerogenes being the principal contaminant. These organisms were frequently missed when incubated in bile salt broth at $37^{\circ} \mathrm{C}$.; but at $22^{\circ}$ and $30^{\circ} \mathrm{C}$. they were readily detectable. Mixed cultures of slime-producing organisms were also occasionally present.

The second paper-reading session, on July 28, opened with a paper on factors affecting the bacterial population of lake waters by Dr. C. B. Taylor, of the Freshwater Biological Association, Wray Castle, Ambleside. The bacteria present in lake water may be considered in three categories : (a) those washed in from outside sources, of which a large population will ultimately perish although others may find conditions suitable for growth; (b) indigenous bacteria capable of existence in a dilute nutrient solution, as represented by lake water, and able to use for growth low concentrations of available organic matter, such types being probably ubiquitous; (c) bacteria dependent on a solid surface for their 